\title{
Explanation of Imam Al-Tirmidhi in Conflicting Islamic Jurisprudence
}

\author{
Ahnaf Wafi Alias \\ Islamic Studies Faculty, The National University of Malaysia \\ Email: awhaukm@gmail.com
}

\author{
Ahamad Asmadi Sakat \\ Senior lecturer in the Department of al-Qur'an and al-Sunnah, Islamic Studies Faculty, \\ The National University of Malaysia.Email: aas@ukm.edu.my \\ Latifah AM
}

Assoc. Prof. in the Department of al-Qur'an and al-Sunnah, Islamic Studies Faculty, The National University of Malaysia. Email: umilm@yahoo.co.uk

\section{Doi:10.5901/mjss.2014.v5n23p310}

\section{Abstract}

The Jami al-Tirmidhi is one the hadith scriptures that explains a lot about the main problems in Islam, such as Islamic jurisprudence (fiqh), beliefs (aqidah) and Islamic etiquette (adab). When discussing the problems associated with fiqh, Imam alTirmidhi had gathered quotes from various hadith that have been argued upon by numerous fuqaha (experts on Islamic jurisprudence) while elaborating on their various opinions over time until this present day. These various opinions and views found in the Jami al-Tirmidhi were compiled to discuss the problems associated with khilaf (comparative or conflicting). Thus, there is a need among researchers to examine and understand the methods used by the Imam in explaining these differences in opinion. There are numerous means to identify khilaf in his works. This research intends to explain the method used by Imam al-Tirmidhi to elaborate on khilaf via the technique of interpreting tarjamah mursalah. Some forty hadith that discussed khilaf pertaining to interpreting tarjamah mursalah were chosen as examples and only one example in the discussion would be explained in this study. This qualitative study used the literature review framework and obtained research data through document analysis. In general, it was found that Imam al-Tirmidhi used the interpretation of current issues to explain khilaf and has his own methods for solving khilaf in opinions (conflict of opinions) among the ulama (religious scholars). Hence, understanding Imam al-Tirmidhi's method of writing in his Jami is important in ensuring no negative assumptions are formed towards an imam, muhaddith (interpretor of the hadith), mujtahid (authority on Islamic law) or murajiih.

Keywords: Imam al-Tirmidhi's methodology; Jami al-Tirmidhi; khilaf (conflicting); interpreting current issues (tarjamah mursalah); problems associated with Islamic jurisprudence (figh).

\section{Introduction}

The arrangement of chapter headings in a hadith is an important element for an author because the author's way of thinking is reflected in the arrangements. A gifted author is capable of exposing the greatness of the contents by having headings that are concise and systematic. Hence, the arrangement of titles also plays a part in ensuring the capability of the author in delivering certain information. Thus, the same principle applies to the Jami, whereby Imam al-Tirmidhi had used his expertise to explain the position of the hadiths and explain the thoughts of the fuqaha during his time. The arranged titles were divided into three sections, namely the interpretation of the zahiriyyah, istinbatiyah and mursalah.

Therefore, since one of imam al-Tirmidhi's intentions of writing the Jami was to explain the thoughts of the fuqaha, hence, the scope of the discussions cannot divert from the problems associated with khilaf (conflict). Among the methods used by imam al-Tirmidhi in explaining khilaf was by using the interpretation of tarjamah mursalah. Hence, to know about khilaf, the researcher has to identify certain current issues that reflect khilaf (conflict) and its relationship with comparative figh (comparative Islamic jurisprudence). 


\section{Literature Review}

This section looks at the various definitions of khilaf (conflicting), understanding the ulama's khilaf, khilaf in al-Jami alTirmidhi, as well as prior researches on this title.

\subsection{Definitions of khilaf (conflicting)}

The subject of khilaf is closely associated with a person's understanding of some matter. According to Ibrahim Mustafa (n.d, p.250), khilaf means something that changes and destroys. It can also mean two things that cannot be consolidated or are not the same. Al-Fairuz Abadi $(2005$, p.808) iterated that khilaf was taken from the religious attestation "ikhtalafa", which means to oppose and to the attestation "ittafaqa", which means to collude or compromise. While, khilaf according to Ibn Manzur (1994, p.90) means something that opposes another. The author has chosen the definition of khilaf as a difference in opinion that naturally cannot be consolidated or colluded by the ulama (intellectuals) about its religious righteousness.

\subsection{Understanding the ulama's khilaf}

Every human has differing opinions about something. Differences in opinion occur due to educational background, level of understanding, family upbringing, society and time that influences a person's thinking. In addition, Islam forbids its followers to disagree and disunite dur to matters pertaining to usul (methods of deduction) but its does not forbid them from having differences in opinion on matters pertaining to furu (in the branch of problem) as long it is based on concrete arguments. This is because what might have public interest (maslahah) at one moment in time might be irrelevant at another time and place. Thus, matters of public interest cannot be avoided and can happen at any time and place. Hence, Islam has set several guidelines when facing matters related to khilaf (conflicts).

\subsection{Khilaf in al-Jami al-Tirmidhi}

Overall, this research intends to identify Imam al-Tirmidhi's methodology in elucidating the ulama's khilaf (conflicting views) found in the Jami scripture. Ahamad Asmadi (1998, p.258) iterated that Imam al-Tirmidhi usually adduced hadith reflecting the prophet's says into two chapters that contained a lot of narrated hadith. Each opinion from a group was adduced in a chapter, accompanied by hadith that touches on the matter of public interest. Hence, this is the Imam's method if there occurs a conflict in religious righteousness $(h u k m)$ regarding matters of public interest, whereby the Imam creates a chapter and later mentions the khilaf. In addition, a guideline on the method of comprehending the ulama's khilaf would be created, especially when comprehending the Jami Imam al-Tirmidhi scripture.

\section{Research Methodology}

This is a qualitative research using the content analysis approach. Among the main documents used is the Sunan alTirmidhi scripture by Abu Isa Muhammad bin Isa bin Sawrah bin Musa bin al-Dahak al-Tirmidhi. This scripture is the main source of reference because the researcher had used several chapters as the research sample to explain how Imam alTirmidhi's methodology explains the interpretation of tarjamah mursalah, especially those involved in khilaf. The second scripture is the Tuhfat al-Awhadhi bi Sharh Jami al-Tirmidhi by Muhammad Abd al-Rahman Abd al-Rahim al-Mubarakfuri, which is an elaboration on the Jami al-Tirmidhi scripture and inadvertently throws some light on the views of the ulama on a particular hadiths and whether it elucidates the ijma, khilaf (conflicts), furu (normative rulings) or nasikh mansukh (abrogation). Besides that, another scripture, the al-Imam al-Tirmidhi wa al-Muwazanah Baina Jamiihi wa Baina alSahihain which was written by Nur al-Din Itr, is also a main source of reference that touches on manhaj (methods) alImam al-Tirmidhi in his Jami. These scriptures were used to accurately analyse data related to Imam al-Tirmidhi's methods in elaborating on khilaf, especially those discuss about the tarjamah mursalah. Besides that, the researcher had used thesis, journals and articles to collect data related to Imam al-Tirmidhi's methodology in elaborating khilaf. 


\section{Findings and Discussion}

\subsection{The Method of Identifying Khilaf in Jami al-Tirmidhi}

According to our opinion, the Imam al-Tirmidhi had used five methods to illustrate khilaf, namely mentioning khilaf clearly, mentioning khilaf by referring to specific terms, mentioning khilaf according to the sect (mazhab), mentioning khilaf according to the chapters discussed and using the tarjamah mursalah technique. The first method can be identified by examining the word "khilaf" or a word that carries the same meaning in the Jami al-Tirmidhi scripture. When identifying the second method, the researcher needs to examine a few terms that are frequently used by Imam al-Tirmidhi when explaining khilaf, such as "amal inda akthar ahl al-ilm", "amal inda ahl al-ilm" dan "amal inda ba'd ahl al-ilm".

The third method used by Imam al-Tirmidhi is to mention the sect's khilaf separately. This method is identifiable when he adduces a particular hadith, followed by an imam's opinion or opinions of several imams that eventually indicates the conflict in opinions. Meanwhile, the fourth method illustrates the khilaf issues related to discussions on the chapter headings. This method was identified when Imam al-Tirmidhi mentioned a hadith in a particular heading and the opinions of a fuqaha. Then came another hadith that was related to the same public interest under the next heading while mentioning an opinion of another imam.

Next, Imam al-Tirmidhi explained khilaf using the al-tarjamah al-mursalah technique. This method was identified through titles written in four ways, name "bab", "bab minhu", "bab minhu akhar" and "bab minhu aidan". All these four ways explain a particular maqasid when explaining the ulama's khilaf. All the five methods can be summarized as follows:

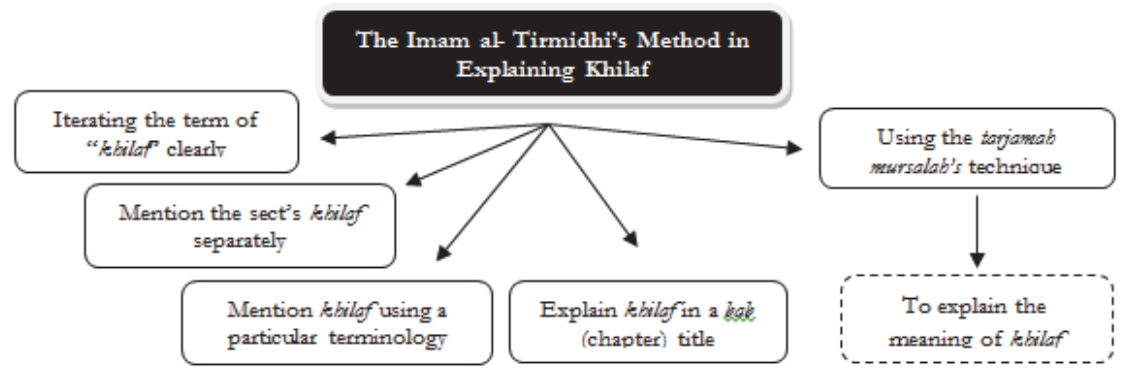

\subsection{Using the al-tarjamah al-mursalah technique to explain khilaf}

Imam al-Tirmidhi had used the 'tarjamah mursalah', which was the word Bab, with no subsequent words such as Bab Minhu, Bab Akhar, Bab Minhu Akhar and Bab Minhu Aidan in his writings. He used this technique to explain ijmak, nasikh mansukh, masalahah furu and khilaf. In explaining the khilaf figh, Imam al-Tirmidhi had used "Bab" three times, such as in Abwab al-Hajj (hadith 907) and twice more in Abwab al-Buyu (hadith 1257 and 1264). The religious attestation (kalimah) "Bab Minhu" was used nine times as in Abwab al-Salat (four times in hadith 150, 304, 362, 442); Abwab alSawm (once in hadith 795); Abwab al-Hajj (twice in hadith 932 and 942); Abwab al-Janazah (one in hadith 995) and Abwab al-Nikah (once in hadith 1114).

Besides that, the use of "Bab Akhar" to explain khilaf was used only once as in Abwab al-Salat (hadith 426). Imam al-Tirmidhi had used the term "Bab Minhu Akhar" in Abwab al-Salat three times (hadith 211, 267 and 269). Meanwhile, the term "Bab Minhu Aidan" was used four times in Abwab al-Salat (hadith 289, 290, 293 and 296).

\subsection{Examples of the "tarjamah mursalah" Technique}

One of the uses of this method is to explain khilaf that occurs when discussing an issue on figh. For example, it could be applied in discussions related to capital rotations, as narrated in this hadith:

Meaning:

Muhammad bin Bashar reported that Abd al-Rahman bin Mahdi who from Sufyan who from Mansur from Ibrahim who from al-Aswad who from Aisyah said that he wished to buy a slave named Barirah. Hence, the family had laid the condition of wala' (capital rotation) for them. The Prophet s.a.w. exhorted, "Buy him, as the wala' belongs to the one who pays or sets the other to freedom." (al-Tirmidhi 1975, v.3, p.548) 
Abu Isa said: "There is a story in this chapter that has been told by Ibn Umar. The hadith by Aishah is authoritative (hasan sahih) and part of the wise scholars has practiced this hadith." He added something about the hereditary lineage of the hadith by saying, "Mansur bin al-Mu'tamir is better known as Abu Attab." Abu Bakr al-Attar al-Basri narrated to us from Ibn al-Madini, he said, "I heard Yahya bin Sa'id saying, I you heard the story from Mansur, then you have delivered goodness and you would not anything else". Then Yahya said, "I did not obtain this story from Ibrahim al-Nakha'i. Hence, Mujahid is better trusted then Mansur". Muhammad had told me what Abdullah bin Abi al-Aswad, Abd alRahman bin Mahdi had said, "Mansur is the most trustworthy among the people of Kufah". (al-Tirmidhi 1975, v.3, p.549).

This hadith elucidates on the need to apply the wala' condition in buying and selling transactions and this was initiated by the Prophet s.a.w. himself. In the next bab, Imam al-Tirmidhi does not mention the title specifically and brought about the following hadith:

\begin{abstract}
Meaning: Abu Kuraib reported that Abu Bakr bin Ayyash who from Abi Husain from Habib bin Abi Thabit who from Hakim bin Hizam said that The Prophet s.a.w. had chosen Hakim bin Hizam as the representative to sell life stock for sacrifice for a few dinars, hence, they were sold with a profit and the rest of the life stock as well. Thus, when the life stock and the dinar were surrendered to the Prophet s.a.w., the Prophet s.a.w. had exhorted: "Sacrifice this lamb and donate the earnings." (al-Tirmidhi 1975, v.3, p.550).
\end{abstract}

The hadith in this chapter (bab) is a continuation from the previous chapter (bab), whereby in the wala' condition be present. Inadvertently, in this hadith, the Prophet s.a.w. did not allow Hakim bin Hizam to claim the profits obtained by selling the life stock meant for sacrificial purposes and ordered that the profits be donated because the sacrificial life stock were slaughtered in order to bring it closer to Allah s.w.t. Therefore, it is detestable (makruh) to claim the profits. Hence, this hadith has not escaped the criticism of the ulama's regarding its authenticity because Habib bin Abi Thabit did not hear it from Hakim bin Hizam (al-Mubarakfuri n.d, p.392). Furthermore, Sheikh al-Albani had categorised this hadith as weak (dacif).

Hence, thereafter Imam al-Tirmidhi had brought this hadith:

\begin{abstract}
Meaning: Ahmad bin Sa'id al-Darimi reported from Habban, who is Ibn Hilal Abu Habib al-Basri, who from Harun alA'war al-Muqri' who from Ibn Musa al-Qari who from al-Zubair bin al-Khirrit who from Abi Labid from Urwah al-Bariqi who said, "The Prophet s.a.w. had given one dinar to me to buy a goat but I bought two goats with that money. Hence, I had sold one goat for one dinar and brought the other goat to the Prophet s.a.w. and conveyed to the Prophet s.a.w. what had transpired. Hence, the Prophet s.a.w. exhorted, "I pray that Allah would bless you for that transaction". After that incident and a few days later he had gone to the market in Kufah and there he had gained huge profits and became the richest man in Kufah." (al-Tirmidhi 1975, v.3, p.551).
\end{abstract}

Abu Isa had said, "A portion of the ulama's sermonette with this hadith. This is the opinion of Imam Ahmad dan Ishaq. The rest of the ulama's did not sermon with this hadith and they were al-Syafi'i, and Sa'id bin Zaid, who was a relative of Hammad bin Zaid. The name Abu Labid is actually Limazah bin Zabbar (al-Tirmidhi 1975, v.3, p.551)

This hadith consolidates the authority on the feature of 'highly probable' (mubah), especially for representatives who sell merchandise at a price far more than that set by the supplier. This happens because the condition stipulated by the owner or supplier has been achieved hence the representative or merchant would charge extra for greater profits. Hence, it is allowed if the owner or supplier had set the representative to sell at one dirham but the representative sells at two dirham. This opinion was agreed by Imam Malik and Ahmad in one of the writings and al-Syafi'i in his qawl al-qadim (al-Mubarakfuri n.d, p.393).

Therefore, these were the tarjamah mursalah technique used by Imam al-Tirmidhi in explaining khilaf. The reason for using this technique was to give a clear picture to scripture researchers on the difference in opinion among the fuqaha based on the arguments of authority (dalils) they have. Hence, this technique appears to be one writing style that is difficult to identify in the discussions found in his scriptures.

\title{
5. Concluding Remarks
}

It can be summarized that imam al-Tirmidhi had used numerous approaches when explaining the khilaf among ulama's. Among them is the use of the tarjamah mursalah approach. This approach is in tandem with his intention to write his Jami scripture, which is to briefly explain the illah hadith and adduce the opinions of the sahabah, tabi'in and fuqahas until his time. Briefly, Imam al-Tirmidhi has succeeded in combining two sects (mazhab), namely the muhaddithin (traditionist) and 
the fuqaha (jurists) in solving problems related to religion. This research is intended to facilitate readers in understanding the method of tarjamah mursalah by Imam al-Tirmidhi, especially in explaining the questions on khilaf among ulama's. This is because he has adduced the subject of khilaf in his Jami scripture. Hence, it is not necessary for him to argue based on these authoritative opinions and views since he is already an imam, muhaddith (traditionist), mujtahid (striving to seek the truth) and murajjih (being superior). It is hoped that this research would help society to evaluate the scholarly attributes and prowess of Imam al-Tirmidhi in explaining figh al-hadith pertaining to tarjamah mursalah. Besides that, it is the intention of the researcher to create awareness among society regarding the method of interacting with the hadith and opinions of ulama's in order to avoid any suspicion towards the teachings delivered by the Prophet Muhammad SAW.

\section{References}

Abdul Latif bin Abdul Haliff. (2008). Metodologi al-Imam al-Tirmidhi R.A dalam kitab al- Shamail al-Muhammadiyyah. Dissertation, Department of al-Quran dan al-Hadith Part of Pengajian Usuluddin, Universiti Malaya.

Ahamad Asmadi bin Sakat and Wan Nasyrudin bin Wan Abdullah. (2007). Isu-Isu Permasalahan Hadith dan al-Kutub al-Sittah. Bank Al Hadith: Satu Keperluan. p.1-31. Bangi: Department of al-Quran dan al-Sunnah, The National University of Malaysia.

Ahamad Asmadi bin Sakat and Wan Nasyrudin bin Wan Abdullah. (2007). Seminar al-Sunah dan Isu-Isu Semasa Peringkat Kebangsaan: Methodologi al-Imam al-Tirmidhi dalam meriwayatkan hadith-hadith yang menunjukkan Bab Tertentu. Bangi: Department of al-Quran dan al-Sunnah, The National University of Malaysia.

Ahamad Asmadi bin Sakat. (1998). Metodologi al-Imam al-Tirmidhi dalam Kitab Sunannya (Jaminya): Kajian Perbandingan dengan Metodologi Sunan Ibn Majah. Master's Thesis Department of al-Quran dan al-Sunnah, The National University of Malaysia.

Ahamad Asmadi bin Sakat. (2007). Junal Islamiyyat Jil 29: Jenis dan Istilah dalam Jami al- Tirmidhi: Satu Kajian. Bangi: The National University of Malaysia.

Ahamad Asmadi Sakat, Mohamad Zaid Mohd Zin, Mohd Arip Kosmo, Mohd Roslan Mohd Nor. (2011). The Dominance of al-Turmudhi's Theological Verdict In His Book al-Jami. Advances in Natural and Applied Sciences 5 (5): 402-408.

al-Albani, Muhammad Nasir al-Din. (1991/1411H). Sahih Sunan al-Tirmidhi. Beirut : al-Maktab al-Islami.

Anon. Kamus Dewan Edisi Keempat. (2005). Kuala Lumpur: Dewan Bahasa dan Pustaka.

al-Fairuz Abadi, Majd al-Din Abu Tahir Muhammad bin Ya'qub. (1426H/2005). al-Qamus al-Muhit. Beirut : Muassasah al-Risalah li alTibah wa al-Nashr wa al-Tawzi.

Ibn Manzur, Abu al-Fadl Jamal al-Din Muhammad bin Mukram bin Ali. (1414H/1994). Lisan al-Arab. Beirut : Dar al-Sadir.

Ibrahim Mustafa, Ahmad al-Zayyat, Hamid Abd al-Qadir dan Muhammad al-Najjar. (n.d.) al-Mu'jam al-Wasit. n.p.: Dar al-Dawah.

al-Khandahlawi. Muhammad Zakaria. (1395H/1975). Muqaddimah al-Kawkab al-Durri Ala Jami al-Tirmidhi. India : Matbaah Nadwah Ulama.

Mohammad Fattah. (2008). Menyingkap hadith-hadith yang di Isyaratkan oleh al-Tirmidhi di dalam Kitab Sunannya : Takhrij hadithhadith Isyarat "Wa Fi al-Bab" di dalam Bab Puasa. Master's Thesis, Department of al-Quran dan al-Sunnah, The National University of Malaysia.

al-Mubarakfuri, Abu al-Ala Muhammad Abd al-Rahman bin Abd al-Rahim. (n.d.). Tuhfat al-Ahwadhi bi Sharh Jami al-Tirmidhi. Beirut: Dar al-Kutub al-Ilmiyyah.

Nazihah binti Jusoh@Muhammad. (2006). Penggunaan Hadith Daif dalam Kitab al-Buyuc: Kajian di dalam Kitab Sunan al-Tirmidhi. Dissertation, Department of al-Quran and al-Hadith Part of Usuluddin Studies, Universiti Malaya.

Nur al-Din Itr. (1988). al-Imam al-Tirmidhi wa al-Muwazanah bayna Jamiihi wa Bayna al-Sahihain. Beirut: Muassasah al-Risalah.

Nur al-Din Itr. (1418H/1997). Manhaj al-Naqd fi Ulum al-Hadith. Syria: Dar al-Fikr Dimashq.

al-Tirmidhi. Muhammad Bin Isa bin Sawrah. (2000). Jami al-Tirmidhi. Riyad, Dar Salam li al- Nash wa al-Tawzi.

Udah@Budah bin Mohsin. Isu-Isu Permasalahan Hadith dan al-Kutub al-Sittah. (2007) Kepentingan Memahami Ulum al Hadith bagi Mempelajari al Hadith dan Kepentingan al-Kutub al-Sittah dalam al-Hadith. p.33-41. Bangi: Department of al-Quran dan alSunnah, The National University of Malaysia. 